\title{
Zusammenhang (Nexus)
}

\author{
Ross SHIELDS
}

To cite this article: Shields, Ross. "Zusammenhang (Nexus)." Goethe-Lexicon of Philosophical Concepts 1, no. 1 (2021): 121-140.

To link to this article: https://doi.org/10.5195/glpc.2021.33

Published by the University Library System, University of Pittsburgh.

\section{(c)}

Entries in this Lexicon are licensed under a Creative Commons Attribution 4.0 United States License.

Copyright @ the Author(s). 


\section{Zusammenhang (Nexus)}

The lexeme Zusammenhang (nexus) was introduced into philosophy by the German rationalists, who conceived of the world as a multiplicity of independent substances coordinated in a system of pre-established harmony. In his critique of these metaphysicians, Kant insisted that things hang together in not one but two ways - as an aggregate of a posteriori sense data, or as a system of a priori concepts - and that these two nexus are separated by an epistemological chasm. This entry proposes that Goethe's nexus concept recovers the middle term excluded by Kant's binary distinction and that this middle term plays a key role in both his scientific and literary writings, including the Hefte zur Morphologie (1817-1824; Notebooks on Morphology), Wilhelm Meisters Lehrjahre (1795-96; Wilhelm Meister's Apprenticeship), and Die Wahlverwandtschaften (1809; Elective Affinities). By comparing Goethe's theoretical use of the nexus concept with his literary use of the nexus motif, this entry articulates a relation of part to whole that displays more coherence than a mere aggregate, yet is more dynamic than an absolute system.

\section{Introduction}

With few exceptions, the word Zusammenhang (nexus, connection, coherence, context; lit. 'hanging-together') is no longer recognized as a philosophical concept. ${ }^{1}$ This is due in part to its ubiquity in contemporary German and in part to a shift in philosophical discourse that has taken place over the last two centuries. The situation is not helped by English translations, which, failing to recognize the word as a terminus technicus, render it variously as "connection, coherence, nexus, pattern, context, structure, complex, interrelatedness, connectedness, and interconnection." ${ }^{2}$ However, Zusammenhang had a clearly defined meaning in the early eighteenth century, when the word was introduced into philosophy as the German equivalent of the Latin nexus, most prominently through Georg Friedrich Meier's translation of Alexander Baumgarten's Metaphysica (1739, trans. 1766): “Der Zusammenhang, die Verbindung und Verknüpfung (nexus) ist das Prädicat, vermöge dessen Etwas entweder der Grund, oder das Gegründete, oder beydes zugleich ist" (The predicate by virtue of which something is either ground or consequence, or both, is the nexus). ${ }^{3}$ Although the rationalist idea of the world as a nexus rerum (Zusammenhang der Dinge, nexus of things) was rendered obsolete by the subjective turn inaugurated by Immanuel Kant's Kritik der reinen Vernunft (1781; Critique of Pure Reason), it survived within his system in modified form, and from there conditioned Goethe's reflections on the relation of part to whole. $^{4}$

Goethe's heterodox use of Zusammenhang not only sets him apart from the philosophical tradition he drew on, but also from the early Romantics and Idealists, who were likewise responding to Kant's philosophy. Following Kant, these thinkers generally held that there were only two ways in which parts could hang together in a whole: as a system, in which an idea of the whole precedes its parts and their connection; or as an aggregate, in which the parts precede the whole to which they add up. ${ }^{5}$ The difficulty presented by Goethe's concept of Zusammenhang is that the relation of part to whole that it describes cannot be reduced to either of these terms: although the whole can be said to condition its parts (as in a system), it does not precede, but emerges from their combination (as in an aggregate). In the context of biology, this implies a rejection of the teleological Bildungstrieb (formative drive) postulated by Johann Friedrich Blumenbach in 1789 to explain the growth and reproduction of organic life, along with the taxonomical system introduced by Carl Linnaeus (1707-1778) in 1735, which erected static divisions between the kingdoms, classes, orders, genera, and species of the natural world. ${ }^{6}$ In the context of art, Goethe's nexus concept makes a definitive break with the Aristotelian primacy of the whole over its parts that had 
been assumed by philosophical aestheticians from the late baroque to the romantic period. ${ }^{7}$ For Goethe, part and whole are both coeval and coevolutionary, preceded-if priority must be established-only by previous iterations of their relationship.

Goethe's unique concept of Zusammenhang allowed him to articulate a highly original theory of organic formation as well as a highly original concept of the work of art. And while both have had an unmistakable influence on subsequent intellectual currents, they remain to a large extent misunderstood-not least because of the tendency to assimilate his ideas to more orthodox philosophical positions, whether Platonism, Spinozism, Kantianism, Hegelianism, or mysticism. ${ }^{8}$ Without denying such influences altogether, this entry assumes the irreducibility of Goethe's nexus concept to any single school. At the same time, it will open certain literary and theoretical texts to philosophical readings, including his essays on comparative anatomy and two of his novels: Wilhelm Meisters Lehrjahre (1795-96; Wilhelm Meister's Apprenticeship) and Die Wahlverwandtschaften (1809; Elective Affinities).

It will be argued that Goethe's concept of Zusammenhang offers an alternative to competing theories of part to whole that accounts for the emergence of complex structure with a minimum of metaphysical presuppositions. But the most compelling reason for examining Goethe's nexus concept lies in how it connects his two major occupations, according to the formula that nature and art hang together insofar as both hang together in the same way. In other words, the analogy between Goethe's scientific and literary production consists in the part-whole relationship shared by these two activities. This entry juxtaposes the nexus concept developed in Goethe's theoretical writings against its literary use, where philosophical problems are less pronounced. On the one hand, it will weigh the significance of Goethe's mereological considerations with respect to aspects of experience that tend to be ignored by traditional ontologies. On the other hand, it will reveal the extent to which Goethe's literary work thematizes the relation of part to whole that it displays.

\section{The Nexus of Things: Rationalism}

Gottfried Wilhelm Leibniz (1646-1716), Christian Wolff (1679-1754), Alexander Baumgarten (1714-1762), and Georg Friedrich Meier (1718-1777) all used the concept of Zusammenhang to articulate a teleological theory of "was die Welt / Im Innersten zusammenhält" (what holds the world together from within) - as Goethe put the question in lines 382-83 of Faust I. ${ }^{9}$ Faced with the problem of explaining how mutually independent substances can interact with one another, these philosophers eventually settled on the system of pre-established harmony, according to which substances do not in fact interact at all. Instead, their reciprocal actions and passions are coordinated by a divine plan, just as the multiple voices of a choir are coordinated by a common score. ${ }^{10}$ Given that perception is a mode of interaction, substances do not perceive one another in any direct sense. ${ }^{11}$ Rather, each substance gradually unfolds a perspectival representation of the nexus of all things past, present, and future, which it contains, and always has contained, within itself.

In his early Reflections on Poetry (1735), Baumgarten extends Leibniz's system of pre-established harmony from the world to the work of art: "We observed a little while ago that the poet is like a maker or a creator. So the poem ought to be like a world. Hence by analogy whatever is evident to the philosophers concerning the real world, the same ought to be thought of a poem." ${ }^{12}$ So the poem, according to Baumgarten, ought to be conceived as a microcosmic "nexus of poetic representations" in which every part is connected to every other by virtue of their all being connected to a single theme, in a harmony that has been pre-established by the poet. ${ }^{13}$ For Baumgarten and his fellow rationalists, the difference between the representations involved in metaphysics and aesthetics is merely one of degree: the metaphysical nexus pertains to the higher cognitive faculty of reason, or the faculty for perceiving the nexus of things distinctly, while the aesthetic nexus pertains to the lower cognitive faculty of sensibility, or the faculty for perceiving the nexus of things confusedly. ${ }^{14}$ According to what he would eventually call the "analogy of reason," the work of art is a tiny world, the artist a minor deity, and aesthetic experience the confused equivalent of metaphysical knowledge (Baumgarten, Metaphysics, §640). ${ }^{15}$

The system of pre-established harmony had achieved philosophical hegemony by the middle of the eighteenth century, when Johann Heinrich Zedler devoted nineteen pages of his Grosses vollständiges Universal-Lexicon (1750; Large and Complete Universal-Lexicon) to an entry on the "Zusammenhang der Dinge" (nexus of things). ${ }^{16}$ However, the doctrine fell into obscurity by the end of the century, in part due to the Pietistic reaction against its alleged fatalism and in part to the philosophical revolution 
E.T.A. Hoffmann (1776-1822) The decline of the rationalist theory of Zusammenhang is documented in E.T.A. Hoffmann's short story, "Der Zusammenhang der Dinge" (1821; The Nexus of Things). Here, a figure named Ludwig discovers the eponymous doctrine in a "verschollenes Buch" (forgotten book). 'While espousing his deterministic belief that the nexus of things resembles "einem großen künstlich zusammengefügten Uhrwerk" (a great artificially assembled clockwork), Ludwig is interrupted by Euchar, who objects to his friend's fatalism in the name of Goethe:

ich weiß nicht, Freund Ludwig! wie du auf einmal zu dieser fatalen, längst veralteten mechanistischen Idee kommst, und Goethes schönen Gedanken vom roten Faden, der sich durch unser Leben zieht, und an dem wir, ihn in lichten Augenblicken gewahrend, den über uns, in uns waltenden höheren Geist erkennen, so entstellen darfst. (Hoffmann, Serapions-Brüder, 1172)

My dear Ludwig! I don't know how you could have suddenly arrived at this fatal, outmoded, mechanistic idea; or how you can so distort Goethe's beautiful notion of the red thread, which runs throughout our life and leads us - as we catch glimpses of it in moments of clarity — to recognize the higher spirit presiding over and within us.

Although Euchar is right to recognize the similarity (and difference) between the rationalist concept of the nexus rerum and Goethe's red thread, his criticism of Ludwig reverses the historical direction of this conceptual tradition: Goethe's red thread - which in its original context describes an obscure connection between the entries of a fictional diary-is better conceived as a distortion of the rationalist nexus of things, with Kant's transcendental idealism mediating between the two. ii

i. E. T. A. Hoffmann, Die Serapions-Brüder (Frankfurt a.M.: Insel, 1983), 1172. Hereafter cited as (Hoffmann, Serapions-Brüder).

ii. For the original use of the metaphor, which literally refers to the red thread running through the ropes of the English navy, marking them as property of the king, see FA 1.8:401.

inaugurated by Kant, who displaced all connection from the object to the subject.

\section{The Nexus of Appearances: Kant}

Kant assigned Baumgarten's Metaphysica (1739) as a textbook for his lectures on metaphysics between 1762 and 1795. Although he praised the rationalists for posing the question of "wie überhaupt Substanzen in commercio mit einander möglich sind?" (Kant, AA 29:865; how substances in interaction with one another are at all possible?), he became critical of two related aspects of their solution. ${ }^{17}$ First, he argued that the system of pre-established harmony concerns only the appearances of things in time and space and not those things in themselves. ${ }^{18}$ Second, he insisted that the difference between the higher and lower cognitive faculties is not one of degree-as the rationalists had maintained - but one of kind, such that sensibility pertains exclusively to appearances and reason to things in themselves. ${ }^{19}$ Unlike the rationalists, for whom the higher and lower cognitive faculties intuit the same nexus of things with different degrees of clarity, Kant divides both mind and world into two sets of incommensurate domains: sensibility intuits the "nexus idealis" (Kant, AA 29:867; ideal nexus) as an aggregate of isolated appearances connected only in time and space, whereas reason projects a "nexus realis" (Kant, AA 29:868; real nexus) beyond appearances in the form of a metaphysical system. ${ }^{20}$

For Kant, the failure to distinguish properly between these two nexus-what he calls the fallacy of subreption-is the source of all major philosophical problems, including the famous antinomies of pure reason..$^{21}$ This does not, however, imply that the aggregate of appearances and the system of metaphysical truths have nothing to do with each other. On the contrary, the gap between their distinct spheres is mediated by the empirical understanding, which is not only responsible for connecting the aggregate of appearances into empirical concepts, but is also tasked with connecting the resulting aggregate of empirical concepts in approximation of a rational system. Kant summarizes this argument in the appendix to the transcendental dialectic of the Kritik der reinen Vernunft: 
Übersehen wir unsere Verstandeserkenntnisse in ihrem ganzen Umfange, so finden wir, daß dasjenige, was Vernunft ganz eigentlich darüber verfügt und zu Stande zu bringen sucht, das Systematische der Erkenntnis sei, d. i. der Zusammenhang derselben aus einem Prinzip. Diese Vernunfteinheit setzt jederzeit eine Idee voraus, nämlich die von der Form eines Ganzen der Erkenntnis, welches vor der bestimmten Erkenntnis der Teile vorhergeht und die Bedingungen enthält, jedem Teile seine Stelle und Verhältnis zu den übrigen a priori zu bestimmen. Diese Idee postuliert demnach vollständige Einheit der Verstandeserkenntnis, wodurch diese nicht bloß ein zufälliges Aggregat, sondern ein nach notwendigen Gesetzen zusammenhangendes System wird. (Kant, KrV B673, A645)

If we survey the cognitions of our understanding in their entire range, then we find that what reason quite uniquely prescribes and seeks to bring about concerning it is the systematic in cognition, i.e., its interconnection based on one principle. This unity of reason always presupposes an idea, namely that of the form of a whole of cognition, which precedes the determinate cognition of the parts and contains the conditions for determining a priori the place of each part and its relation to the others. Accordingly, this idea postulates complete unity of the understanding's cognition, through which this cognition comes to be not merely a contingent aggregate but a system interconnected in accordance with necessary laws. ${ }^{22}$

Although Kant had already proposed in the Kritik der reinen Vernunft that the rational idea of a system provides the empirical understanding with a regulative principle for connecting the aggregate of empirical concepts into a scientific system, he modifies and expands this argument in the Kritik der Urteilskraft (1790; Critique of the Power of Judgment) to account for two additional phenomena: beauty and organic form..$^{23}$ Reflective judgments of both, he now argues, involve the presupposition of "Zweckmäßigkeit" (Kant, KU B69, A68; purposiveness) without the determination of any definite "Zweck" (Kant, KU B69, A68; purpose).$^{24}$ On the one hand, beautiful forms present us with an aggregate of appearances that we judge as if they were purposively connected according to an unknown rule. On the other hand, organic nature presents us with an aggregate of mechanical laws - the "nexus effectivus" (Kant, KU B289, A285; effective nexus) that we judge as if they were purposively connected in a teleological system or "nexus finalis" (Kant, KU B290, A286; final nexus). Hence, while Kant is critical of rationalist metaphysics and aesthetics, he subsumes the nexus involved in both - along with their analogy-into his own philosophical system.

\section{The Excluded Middle: Goethe}

In an essay titled "Einwirkung der neueren Philosophie" (1817; The Influence of Recent Philosophy), Goethe recalls how Kant's Kritik der Urteilskraft, which he read within a year of its publication, inaugurated one of the happiest periods of his life: "Hier sah ich meine disparatesten Beschäftigungen neben einander gestellt, Kunst- und Naturerzeugnisse eins behandelt wie das andere, ästhetische und teleologische Urteilskraft erleuchteten sich wechselweise" (FA 1.24:444; Here I saw my most disparate occupations set beside each other; works of art and works of nature each treated in like manner; the aesthetic and teleological powers of judgment mutually illuminating each other). In this respect he was the contemporary of a number of romantic and idealist poets and philosophers, including Friedrich Schlegel, Novalis, Schelling, and Hegel, who each in his own way developed Kantianism beyond the narrow limits that Kant had placed on discursive knowledge. ${ }^{25}$ However, Goethe's scientific and artistic pursuits differed from those of his contemporaries - as from those of his philosophical antecedents - to the extent that he discarded the dualistic assumption that there are only two ways in which parts can hang together in a whole. Not only does he insist, as in "Analyse und Synthese" (1829, Analysis and Synthesis), that there is no point in analyzing that whole which is "nur eine Aggregation" (FA 1.25:85; merely an aggregation). ${ }^{26} \mathrm{He}$ also rejects, in "Problem und Erwiderung" (1823; Problem and Rejoinder), the idea that nature-let alone its scientific representation - is or should be systematic: "Die Natur hat kein System, sie hat, sie ist Leben und Folge aus einem unbekannten Zentrum, zu einer nicht erkennbaren Grenze" (FA 1.24:582; Nature has no system. It has and is life and consequence from an unfamiliar center to an unknowable border). 
Goethe's refusal to choose between the Kantian set of binary oppositions-aggregate or system, appearance (nexus idealis) or substance (nexus realis), mechanism (nexus effectivus) or teleology (nexus finalis) - led him to make an original contribution to philosophy and natural science. Indeed, it anticipates a number of theoretical positions that have emerged in the twentieth and twenty-first centuries as the result of similar responses to transcendental idealism, including Alfred North Whitehead's philosophy of organism, Gilles Deleuze and Felix Guattari's theory of assemblage, and Jane Bennett's vital materialism. ${ }^{27}$ However, any analysis of Goethe's nexus concept would be incomplete without taking into account his use of Zusammenhang as a literary motif-especially in his novels published after 1796, by which time he had made his most important morphological observations. Although it may be tempting to try to reduce Goethe's literary production to his theory of nature - or vice versa - an analysis of the development of his thought suggests that the relations between them is one of analogy: much in the way that Baumgarten defines aesthetics as the "analogy of reason," or that Kant constructs an analogy be- tween teleological and aesthetic judgment. The following four sections will present two aspects of this analogy by juxtaposing passages from Goethe's theoretical and literary writings, first as they concern the mereological character of Zusammenhang (reducible to neither system nor aggregate), and then as they concern its genesis (reducible to neither mechanism nor teleology). ${ }^{28}$

\section{Goethe's Concept of Theory}

"Die Theorie an und für sich ist nichts nütze, als insofern sie uns an den Zusammenhang der Erscheinungen glauben macht" (FA 1.10:571; In and of itself, theory is only useful insofar as it makes us believe in the nexus of appearances). At first glance, Goethe's statement-which he placed in a collection of aphorisms in his last novel, Wilhelm Meisters Wanderjahre (1821/29; Wilhelm Meister's Journeyman Years), under the title "Betrachtungen im Sinne der Wanderer" (Observations in the Spirit of Travelers) - recalls the regulative function that Kant had assigned to reason, which grounds our otherwise unsubstantiated belief that the aggregate of appearances can be connected into a

Romantic Disambiguation A rare analysis of the word Zusammenhang is offered by Wilhelm von Schütz, a lesser-known romantic poet who published his own Hefte zur intellectuellen und substantiellen Morphologie (1821; Notebooks on Intellectual and Substantial Morphology) as a response to Goethe's scientific project. First, Schütz distinguishes "Zusammenhang" from the mechanical "Verbindung" (connection) among the isolated moments of an aggregate:

Man betrachte nur beide Wörter, Verbindung und Zusammenhang; das wahre Verhältnis liegt in der Darstellung, die sie geben. Macht das Wort verbunden nicht, daß wir Dinge annehmen, die, sich gegenseitig fremd und unabhängig, lediglich von Außen an einander gefügt werden?

One need but consider both words, connection and hanging-together; the true relationship lies in the presentation which they give. Doesn't the word connection imply that we hypothesize things that are foreign and independent from each other, and are merely joined to each other from outside?

Schütz then distinguishes "Zusammenhang" from the "Einheit" (unity) proper to a system:

Es stand, wenn [das Wort Zusammenhang] unbenutzt blieb, nur ein anderes Wort zu Gebot, das Wort Einheit. Dessen Wahl aber hat sonstige Bedenken. Der Inhalt dieses Worts entzieht sich der Anschauung völlig, und gibt deshalb nie einen festen Begriff. Anschauung und Begriff, statt sich zu entsprechen, wiedersprechen sich bei diesem Wort. (Schütz, Zur Morphologie 55)

There is, should hanging-together not be used, another word at our disposal, the word unity. But its choice raises other concerns. The content of this word eludes our intuition entirely, and for that reason can never provide us with a firm concept. Intuition and concept, instead of corresponding to each other, contradict each other in this word. 
Schütz concludes by defining Zusammenhang as a middle term between unity and connection that describes a morphological relationship among semi-dependent parts: "Das Wort Zusammenhang [...] gewährt eine Anschauung, die sich in der Erscheinung wiederholt. Es war dem morphologischen Zweck günstig, und hielt, wenn Einheit ganz auf Intellectuelles, Verbindung ganz auf Substantielles zu beziehen gewesen wäre, eine willkommene Mitte; denn es hat eine Beziehung auf Beides" (Schütz, Zur Morphologie 59; The word hanging-together allows for an intuition which repeats itself in appearances. It was well suited to the morphological aim and constitutes a welcome middle, if unity is referred entirely to the intellect and connection entirely to substance; for it has reference to both). Although Schütz can be faulted for the mystical character of his morphological reflections, he should be credited with the early recognition that Goethe's nexus concept can be reduced to neither the unity of a system nor the essentially independent parts of an aggregate connected by an external principle.i

i. Wilhelm von Schütz, Zur intellectuellen und substantiellen Morphologie, vol. 1. (Leipzig, 1821), 55. Hereafter cited as (Schütz, Zur Morphologie).

ii. See Goethe's letter to Friedrich Wilhelm Riemer on October 2nd, 1822, which criticizes Schütz for venturing into "düstern Gegenden, wohin zu folgen mir ganz unmöglich ist" (obscure regions where it is entirely impossible for me to follow). Johann Wolfgang Goethe, Die Schriften zur Naturwissenschaft, ed. Dorothea Kuhn (Weimar: Hermann Böhlaus Nachfolger, 1986), 210A:542. Hereafter cited as LA in the body of the text. For Schütz's characterization of the form of Goethe's notebooks on morphology, see Geulen, Aus dem Leben 122. For Schütz's ties to romanticism, see Helmut Sebdner, Schütz-Lacrimas: Das Leben des Romantikerfreundes, Poeten, und Literaturkritikers Wilhelm von Schütz (Berlin: Erich Schmidt Verlag, 1974).

unified system of nature. ${ }^{29}$ However, Goethe is far from endorsing Kant's principle of transcendental purposiveness - with or without a definite purpose-which would reintroduce the rationalist system of pre-established harmony in the guise of a regulative principle..$^{30}$ In another aphorism from the same collection, he instead proposes that phenomena are immediately connected only to those nearest to them. Consequently, scientists who extend a particular finding beyond its relevant local context are committing a theoretical error:

die Gebildeten [können] es selbst nicht lassen[], wenn sie an Ort und Stelle irgend ein Wahres erkannt haben, es nicht nur mit dem Nächsten, sondern auch mit dem Weitesten und Fernsten zusammen zu hängen, woraus denn Irrtum über Irrtum entspringt. Das nahe Phänomen hängt aber mit dem fernen nur in dem Sinne zusammen, daß sich alles auf wenige große Gesetze bezieht die sich überall manifestieren. (FA 1.10: 575-76)

not even educated people, having recognized a truth in a particular place, can avoid connecting [zusammenzuhängen] it not only to what is closest, but to what is most remote and most distantwhich leads to error upon error. But the close phenomenon only hangs together [hängt [...] zusam$m e n]$ with the distant phenomenon in the sense that everything refers to a few great laws that manifest themselves everywhere.

Besides the small number of general laws that can claim universal application, truth has a merely local validity. Hence, while Goethe agrees with Kant and the rationalists that knowledge consists in connections among representations, he rejects the totalizing pretension of their various philosophical systems, concluding instead that, for the most part, this connection is indirect, facilitated by countless intermediary links. Theory, in making us believe in the "Zusammenhang der Erscheinungen" (nexus of appearances), has no other role than to anticipate the existence of such intermediaries.

Goethe's insistence on the local validity of truth should not be interpreted as a positivistic position. He is far from substituting the ideal of a system with a mere aggregate of disconnected facts. Although he warns against the haste with which researchers tend to generalize their findings, he is just as critical-in a posthumous fragment-of the tendency to overload an isolated observation or experiment with unwarranted significance, as Isaac Newton had supposedly done in his prism experiment of 1666. In a sense, both kinds of methodological error amount to the same thing:

Ein Phänomen, ein Versuch kann nichts beweisen, es ist das Glied einer großen Kette, das erst im Zusammenhange gilt. Wer eine Perlen- 
schnur verdecken und nur die schönste einzelne vorzeigen wollte, verlangend wir sollten ihm glauben die übrigen seien alle so, schwerlich würde sich jemand auf den Handel einlassen. (FA 1.13:17)

A single phenomenon, a single experiment, proves nothing; it is the link in a great chain that is first valid in its connection [im Zusammenhange]. One would hardly do business with someone who would hide a string of pearls and show us only the most beautiful individual specimen, asking us to believe that the rest are of the same quality.

No doubt: Goethe's theory of colors is an attempt to display this chain as such. ${ }^{31}$ According to him, truth is neither universal nor singular, but is gradually built up by stringing series of phenomena together like pearls in a necklace. But even this image is misleading to the extent that it suggests that phenomena are encountered in the order with which they explain each other, as if a casual stroll through a garden were sufficient to develop a botanical theory. On the contrary; it may take years before the intermediary case is discovered that connects two phenomena, and it is up to the researcher to arrange all three in a way that reveals their connection. A famous example of such an aperçu, in which two previously unrelated phenomena are connected by a third, was provoked by the fragment of a sheep's skull that Goethe found on a Venetian beach. This discovery, he explains in "Bedeutende Fördernis durch ein einziges geistreiches Wort" (1823; Significant Help Given by a Single Ingenious Word), led him to recognize the lower cranial bones as transformations of the upper vertebrae: "so fand sich nach Jahren auf einmal alles aufgeklärt in dem schönsten Zusammenhange" (FA 1.24:598; Thus, years later, everything was suddenly illuminated in the most beautiful nexus).

For Goethe, science begins with the collection of phenomena, resists the temptation to subsume them prematurely under more general laws, but instead seeks out the transitions that reveal their affinity in a formal nexus. On this view, the task of theory is not to articulate the a priori categories under which phenomena must be subsumed, but to insist that the nexus through which such phenomena explain each other will reveal itself to the attentive observer. Hence Goethe's advice to Johann Daniel Falk (1768-1826) upon presenting him with a piece of granite:

Betrachten Sie mir ja fleißig diese Übergänge, worauf am Ende Alles in der Natur ankommt. Etwas, wie Sie sehen, ist da, was einander aufsucht, durchdringt und, wenn es eins ist, wieder einem Dritten die Entstehung gibt. [...] Den Zusammenhang aber müssen Sie selbst entdecken, dem hilft es auch nichts, wenn man es ihm sagt. ${ }^{32}$

Pay careful attention to the transitions, upon which everything in nature ultimately depends. As you see, something is there that seeks out another, penetrates it and, having become one, again gives rise to a third. [...] But you yourself must discover the connection [Zusammenhang]; it doesn't help to be told about it.

Without the corresponding intuitions that fill it with meaning, Goethe's concept of Zusammenhang is less than empty, in that it does not even determine the form of the transition between the elements that it relates. ${ }^{33}$ This must instead be supplied with the object and will vary according to its particular character.

\section{The Red Thread Unravels}

Of the many interpretations of Goethe's Wahlverwandtschaften (1809; Elective Affinities), none has managed to do justice to its dense network of symbolic associations, geographical topoi, mimetic resemblances, and interfigural relations - a fact that is evident in the sheer quantity of criticism on the book. Indeed, the failure of any attempt to reduce Goethe's third novel to any particular reading attests to the extent to which it diverges from Baumgarten's rationalist aesthetics, which attributed a hierarchical structure to the work of art wherein every element is subordinated to a single overarching theme. But among the many elements woven together in Die Wahlverwandtschaften, Zusammenhang stands out. On the one hand, the word is used to explain the chemical bonds that lend the book its title. ${ }^{34}$ On the other hand, it prompts reflection on the 
interpretive challenge posed by the novel's complex organization. To say that Die Wahlverwandtschaften is 'about' Zusammenhang is different from saying that it is about chemistry or marriage or the French Revolution, in that this nexus consists in the interweaving of these and many other 'threads'-including the red one connecting the entries of Ottilie's diary. In other words, to say that the novel is about Zusammenhang is merely to raise the question of how its multiplicity of parts hang together as a whole.

This question is complicated by the fact that each of the novel's four protagonists is associated with a different mode or degree of Zusammenhang. In the very first chapter, for example, Charlotte defines her relation to Eduard by distinguishing between the nexus proper to the male and female genders:

Die Männer denken mehr auf das Einzelne, auf das Gegenwärtige, und das mit Recht, weil sie zu tun, zu wirken berufen sind, die Weiber hingegen mehr auf das, was im Leben zusammenhängt, und das mit gleichem Rechte, weil ihr Schicksal, das Schicksal ihrer Familien an diesen Zusammenhang geknüpft ist und auch gerade dieses Zusammenhängende von ihnen gefordert wird. (FA 1.8:274-75)

Men think more about what is singular, what is present, and that is their right, since they are called to action and efficiency. Women on the other hand think more about what hangs together [zusammenhängt] in life, and that with no less right, since their fate, the fate of their families, is connected to this nexus [an diesen Zusammenhang geknüpft] and because just this connection [dieses Zusammenhängende] is demanded from them.

When Eduard responds to Charlotte's characterization of their relationship, he juxtaposes the simultaneity implied in her ideal of coherence against the sequential character of his own discourse and activity:

Da das Zusammenhängende, wie du sagst, eigentlich euer Element ist, [...] so muß man euch freilich nicht in einer Folge reden hören, oder sich entschließen euch recht zu geben [...]. Die Anlage, die wir bis jetzt zu unserm Dasein gemacht haben, ist von guter Art; sollen wir aber nichts weiter darauf bauen, und soll sich nichts weiter daraus entwickeln? (FA 1.8:246-47)

Since what hangs together is, as you say, your element, [...] one need not listen to you in sequence or decide to acknowledge that you are right [...]. The ground on which we have made our existence until now is of the right sort; but should we refrain from building further on it, and should nothing develop from it?

Of course, the topic under debate is not (just) the physical grounds of the estate on which the married couple has built its existence, but whether or not to invite others into their lives - and, as it turns out, to introduce other modes of Zusammenhänge (nexus) into the novel.

The first guest to arrive is the Captain, a man described in the tenth chapter of the first part as "sehr wohl und im Zusammenhang unterrichtet" (FA 1.8:345; very well-educated and knowledgeable about how things connect). He is so well-educated, in fact, that he personifies the topdown organization of a system, albeit devoid of metaphysical pretense. Consider the Captain's survey of Eduard's estate, his criticism of Charlotte's piecemeal landscaping, his organization of a medical station and police force, and his plan to improve the neighboring village..$^{35}$ However, a second houseguest, Ottilie, soon arrives to counterbalance the Captain's systematic rationalism. According to a teacher who has taken an interest in her education, Ottilie rejects anything that is not immediately connected to her interests. We read, in part one of chapter three:

Sie steht unfähig, ja stöckisch vor einer leicht faßlichen Sache, die für sie mit nichts zusammenhängt. Kann man aber die Mittelglieder finden und ihr deutlich machen, so ist ihr das schwerste begreiflich" (FA 1.8:294)

She stands there helpless, stubborn even, before an easily comprehensible matter that for her hangs together with nothing. And yet, if one can find the mediating links and reveal them to her, she is able to grasp the most difficult things.

Unlike the systematic reforms introduced by the Captain, the largely intuitive changes that Ottilie makes in Eduard's and Charlotte's lives are minor to the point of being 
imperceptible. She thus adapts herself to life on the estate, gradually assuming the management of the household, silently correcting the mistakes of the servants, and making sure that Eduard's tea has just the right amount of sugar. ${ }^{36}$

Although one might expect that the Captain's investment in systematic rationalism would complement Ottilie's demand for immediate connections and mediating links, the two figures rarely interact. In one of the few scenes where they do (Book 1 , Chapter 7) the result is conflict. After the small society draws up plans for a new path to the new house that is to be built opposite the main hall, Eduard asks Ottilie for her opinion, insisting that "alles sei [...] noch im Werden" (FA 1.8:325; everything is [...] still in a state of becoming). Encouraged by this remark, she proposes that the new house should be tucked away behind a small forest and out of sight of the main hall in order to offer an overview of the landscape that all had admired during their stroll that day. Eduard immediately seizes upon Ottilie's idea, marking the freshly prepared map with a rectangle on the proposed location, which causes the Captain considerable distress: "Dem Hauptmann fuhr das durch die Seele: denn er sah einen sorgfältigen, reinlich gezeichneten Plan ungern auf diese Weise verunstaltet" (FA 1.8:326; This pierced the Captain through the soul: for he did not like to see a plan that had been cleanly and carefully drawn up deformed in this way). He soon recovers his composure, but not before his character has been distinguished from that of his companions: The impulsive Eduard forges a new path through the estate; the economic Charlotte approves the budget that will make it permanent; the systematic captain draws up a plan to incorporate the novelty; the intuitive Ottilie proposes a minor alteration.

When read in light of Goethe's reflections on theory, the four main figures in Die Wahlverwandtschaften represent four valences of Zusammenhang, with Kant's systematic ideal and Goethe's immediate connection comprising its two extremes. Charlotte and the Captain stand to the side of the whole, with the former seeking to sustain and strengthen the relationship of its given parts, while the latter works to bring them into systematic connection. Accordingly, when they fall in love, their feelings for each other express themselves as reverential distance (on the part of the Captain) and pain at the thought of separation (on the part of Charlotte). Eduard and Ottilie, by contrast, stand to the side of the part, with Eduard spontaneously introducing new elements into the estate and Ottilie trans- forming whatever she encounters to bring it into harmony with its surroundings. When their passionate affair is frustrated, Eduard rashly decides to go to war, leaving Ottilie to sublimate her "Neigung und Anhänglichkeit" (FA 1.8:402; attraction and devotion) in her diary. As long as the prospect of a double separation and remarriage can be entertained, she lives out an imaginary fullness, as the narrator suggests in the seventh chapter of the second book: "Es schien ihr in der Welt nichts mehr unzusammenhängend, wenn sie an den geliebten Mann dachte, und sie begriff nicht, wie ohne ihn noch irgend etwas zusammenhängen könne" (FA 1.8:450; Nothing in the world seemed unconnected [unzusammenhängend] to her when she thought of the beloved man, and she couldn't imagine how anything could hang together [zusammenhängen] without him). But just two chapters later, having given up hope for a happy ending, she concludes her diary-which connects all of its entries with the symbolic red thread-with a reflection on dissolution: "Alles, was auch gutes und bedeutendes vorkommt, hängt nur kümmerlich zusammen. Man muß überall von vorn anfangen und möchte überall enden" (FA 1.8:463; Everything, even good and important occurrences, hangs only barely together. Everywhere one must start over again, and everywhere one would like to end).

The tragic conclusion of the novel reflects the impossibility of reconciling these various modes of organization: there is no room in the Captain's plan for Charlotte, who will do whatever she can to preserve her marriage. Eduard would rather perish than live without Ottilie, who refuses his advances out of consideration for Charlotte and the baby Otto. Neither the traditional relation of part to whole represented by the married couple at the beginning of the novel, the systematic unity introduced by the Captain, nor the delicate coherence effected by Ottilie can establish a stable relationship among all four figures. Ultimately, it is impossible to say which of the various modes of Zusammenhang represented by the four characters wins out, and the quasi-mathematical logic with which the novel begins gradually gives way to chaos and confusion - not least due to the arrival of Charlotte's daughter, Luciane, who is described in the third chapter of the first book as being capable of comprehending "alles, auch das Unzusammenhängende" (FA 1.8:294; everything, even what is unconnected). Indeed, the great irony of Die Wahlverwandtschaften is that the relations among its figures unfold with little regard to their conscious predic- 
tions, intentions, or impulses, suggesting that any attempt to reduce the novel's plot to a single mode of coherencechemical or otherwise-is bound to fail.

\section{Goethe's Theory of Morphology}

Goethe's rejection of Kant's mereological dualism, according to which parts can only hang together as an aggregate or as a system, is nowhere more evident than in his morphological writings. ${ }^{37}$ In the introduction to the first of his Hefte zur Morphologie (1817-1824; Notebooks on Morphology), he criticizes the science of anatomy not so much for dissecting the living whole into complex parts, but for dissecting those complex parts into their simple parts - yielding an aggregate of "Similarteile" (FA 1.24:392; atomic parts $)^{38}$ that no longer bear any trace of organic connection. He then advances morphology as a synthetic corrective to this analytic procedure-a new science that would begin with a collection of complex parts and conclude with an intuition of the whole:

Es hat sich daher auch in dem wissenschaftlichen Menschen zu allen Zeiten ein Trieb hervorgetan, die lebendigen Bildungen als solchen zu erkennen, ihre äußern sichtbaren, greiflichen Teile im Zusammenhange zu erfassen, sie als Andeutungen des Innern aufzunehmen und so das Ganze in der Anschauung gewissermaßen zu beherrschen. (FA 1.24:391)

Hence, scientific minds of every epoch have also felt the need to understand living formations as such, to grasp their outward, visible, tangible parts in a nexus, to view these parts as an indication of what lies within, and thereby gain some command of the whole in intuition. ${ }^{39}$

In a sense, morphology applies the comparative method of natural history to the data furnished by anatomy. If the former seeks to provide an overview of the external forms of nature, and if the latter seeks to provide access to their internal composition, then morphology seeks to provide an overview of the internal natural forms constituting those individuals: the formal affinity of their complex parts, both within a particular plant or animal and across different species. ${ }^{40}$
Far from assuming that the parts of a morphological whole are organized according to a teleological principle of systematic unity, Goethe defines their "Zusammenhang," in a posthumous fragment, as an "organische Harmonie des Ganzen daß es aus identischen Theilen besteht" (LA 2.9B:29-30; organic harmony of the whole insofar as it consists of identical parts). Unlike the Similarteile revealed by anatomist, these parts are "identical" only in the idea, but enter into experience with the greatest diversity of number, size, and shape - as Goethe writes in the introduction to his notebooks on morphology: "das, was der Idee nach gleich ist, [kann] in der Erfahrung entweder als gleich, oder als ähnlich, ja sogar als völlig ungleich und unähnlich erscheinen" (FA 1.25:57 and Miller 65; What is alike in idea may appear in experience as alike, as similar, or even as totally unalike and dissimilar). ${ }^{41}$ Moreover, since identity pertains only to the idea and not to experience, Goethe's definition of organic harmony in terms of identical parts implies that these parts - in experienceare variations of one another, not unlike the musical harmony that results from varying a motif: two forms are identical insofar as one is the transformation of the other; they are similar to the extent that the formal properties of the first are preserved in the second; they are dissimilar to the extent that metamorphosis has introduced more or less difference in response to changing environmental conditions. $^{42}$

For Goethe, what is true of the individual organism is true of nature as a whole, which can likewise be conceived as a harmonious nexus of parts that are identical 'in the idea' and diverse according to the contingent circumstances imposed by experience. At the risk of being schematic, one could summarize this process as follows: in reproducing itself, a given entity is transformed into another one that is better adapted to its circumstances. This second entity can subsequently join itself to the first (or to another preexisting entity), yielding a complex individual. That individual can then transform itself into a second individual, which again adapts itself to its circumstances and, in turn, again enters into novel relations with other entities and individuals. As Goethe writes in a posthumous fragment, the whole of nature is nothing but the mutual dependency of such entities, which reciprocally determine the conditions in which each can grow, reproduce, transform, separate, and reunite: 
so wird man sich nunmehr in der Betrachtung erheben und wird die organisierte Welt wieder als einen Zusammenhang von vielen Elementen ansehen. Das ganze Pflanzenreich z.E. wird uns wieder als ein ungeheures Meer erscheinen, welches eben so gut zur bedingten Existenz der Insekten nötig ist, als das Weltmeer und die Flüsse zur bedingten Existenz der Fische, und wir werden sehen daß eine ungeheure Anzahl lebendiger Geschöpfe in diesem Pflanzen-Ozean geboren und ernährt werde, ja wir werden zuletzt die ganze tierische Welt wieder nur als ein großes Element ansehen, wo ein Geschlecht auf dem andern und durch das andere, wo nicht entsteht doch [sich] erhält. (FA 1.24:214)

one will thus raise oneself in contemplation and again view the organized world as a nexus of many elements. The whole kingdom of plants, for example, will appear to us as an enormous ocean that is as much a necessary condition for the existence of insects as is the world's ocean a necessary condition for the existence of fish, and we will see that a great number of living creatures are born and nourished in this ocean of plants. We will come at last to view the whole world of animals again as one grand element in which one population maintains itselfif not originates - in and through the other.

Like Baumgarten and Kant, Goethe conceives of the world (as well as the individual organism) as a Zusammenhang of elements; however, he accounts for the harmony of this nexus neither by invoking a transcendent purpose nor by presupposing a principle of transcendental purposiveness. Instead, this harmony is the result of what he describes - in "Problem und Erwiderung" (1823; Problem and Rejoinder) - as a tension between two opposing forces: the "centripetal" tendency of an entity to preserve its form across reproduction and the "centrifugal" tendency that allows the new form to adapt itself to a world in constant flux. ${ }^{43}$

\section{Pulling Strings}

If Die Wahlverwandtschaften thematizes the valences of the nexus concept - its various modes and degrees - then
Wilhelm Meisters Lehrjahre (1795-96; Wilhelm Meister's Apprenticeship) is concerned with its genesis. It is in this sense a Bildungsroman (novel of formation). In fact-in a diary entry from around $1820-$ Goethe describes the early stages of the book as "kotyledonartig" (FA 1.17:13; cotyledonesque), referring to the seed leaf of a young plant. Those familiar with his Versuch die Metamorphose der Pflanzen zu erklären (1790; Attempt to Explain the Metamorphosis of Plants), which argues that the cotyledon or seed leaf is the initial form of a plant that undergoes change in all of the subsequent stages of its growth, will recognize in this description an invitation to reflect on the novel as a morphological nexus of parts, such that every motif, figure, and episode is conceived as the transformation of other ones. ${ }^{44}$

The morphological dimension of the Lehrjahre was not lost on its early readers. Friedrich Schlegel (1772-1829) in his essay "Über Goethes Meister" (1798; On Goethe's Meister)-lauded the "freie Behandlung, Gestaltung und Verwandlung" (FA 1.9:1297; free treatment, formation, and transformation) of material from one episode to the next, while Friedrich von Hardenberg (Novalis) (17721801) described its cast of characters as slight mutations of each other: "Lothario ist nichts, als die männliche Therese mit einem Übergang zu Meister. Natalie-die Verknüpfung und Veredlung von der Tante und Therese. Jarno macht den Übergang von Theresen zum Abbé" (FA 1.9:1312; Lothario is nothing but the male Theresa with a transition to Meister. Natalie - the connection and refinement of the aunt and Therese. Jarno makes the transition from Therese to the Abbé)..$^{45}$ And the list goes on and on. However, Goethe's early romantic readership, under the sway of post-Kantian Idealism, could hardly resist attributing a teleological "Bildungstrieb" (FA 1.9:1299; formative drive) to the novel (in the case of Schlegel) or elseupon recognizing this drive to be illusory-condemn the book's "[p]oëtische Maschinerie" (FA 1.9:1314; poetic machinery) (in the case of Novalis). ${ }^{46}$ Organic system or mechanical aggregate. By contrast, Goethe is recorded as having insisted - in a conversation with Johann Peter Eckermann (1792-1854) - that his novel attains its happy ending "ohne ausgesprochene Tendenz" (without pronounced tendency). ${ }^{47}$ In this sense Wilhelm Meisters Lehrjahre reflects the aim of Goethe's morphological project: to account for the emergence of complex structure without the assumption of teleological order. 
The problem of the novel's organization is thematized in two episodes - an initial scene and its repetition - that are connected by their common invocation of the nexus motif, as by their common reference to the theater. ${ }^{48}$ The initial scene takes place in the fourth chapter of the first book, when Wilhelm recalls his childhood astonishment upon glimpsing the backstage workings of a marionette theater: "Nachdem ich etwas erfahren hatte, kam es mir erst vor, als ob ich gar nichts wisse, und ich hatte recht: denn es fehlte mir der Zusammenhang, und darauf kommt doch eigentlich alles an" (FA 1.9:370; Having experienced something, it seemed to me that I knew nothing at alland I was right; for I lacked context [Zusammenhang], and that's what everything depends on). Here, the phrase "es fehlte mir der Zusammenhang" is ambiguous. Although it could refer to the missing context through which Wilhelm would be able to interpret the now lifeless puppets, it also draws attention to the hidden strings that would provide a mechanistic explanation for their former animation.

The repetition of this scene occurs in the ninth chapter of the seventh book, when a second pair of curtains opens onto the inner workings of the mysterious Turmgesellschaft (tower society), which-it turns out-has been pulling the strings on events touching Wilhelm's life since he was a child. When the curtains close again, he is left alone to reflect on the situation: "'Sonderbar!' sagte er bei sich selbst, 'sollten zufällige Ereignisse einen Zusammenhang haben? Und das, was wir Schicksal nennen, sollte es bloß Zufall sein?' " (FA 1.9:872; 'Remarkable!' he said to himself, 'could it be that contingent events hang together? And could it be that what we call fate is mere contingency?'). The strings of the puppets from Wilhelm's childhood are here redeployed as the connection of events that he had previously attributed to fate and are now reduced to the worldly influence of an intradiegetic cabal-as if Wilhelm were himself a marionette caught up in the action of a real-life drama. ${ }^{49}$

Although it may seem that the Turmgesellschaft has merely replaced the strong teleology of fate with the weak teleology of a stage play, two considerations reveal that this is far from being the case.

On the one hand, the Turmgesellschaft-despite its air of mystery-is little more than a group of men pursuing an economic advantage, according to a philosophy that is first articulated by a stranger whom Wilhelm encounters in the last chapter of the first book (and then reencounters during his induction ceremony): "Das Gewebe dieser Welt ist aus Notwendigkeit und Zufall gebildet, die Vernunft des Menschen [...] behandelt das Notwendige als den Grund ihres Daseins, das Zufällige weiß sie zu lenken, zu leiten und zu nutzen" (FA 1.9:423; The fabric of this world is formed of necessity and contingency; human reason [...] treats necessity as the ground of its existence and knows how to steer, direct, and utilize contingency). ${ }^{50} \mathrm{Far}$ from executing a predetermined plan, the Turmgesellschaft expresses its power by 'steering and directing' the course taken by contingent events. This is so much the case that Wilhelm, frustrated by his benefactors' proclivity for mystery and machination, eventually comes to object-in the fifth chapter of the eighth book - to the tangled plot in which he finds himself enmeshed: "So viel ich diese heiligen Männer kenne, scheint es jederzeit ihre löbliche Absicht das Verbundene zu trennen und das Getrennte zu verbinden. Was daraus für ein Gewebe entstehen kann, mag wohl unsern unheiligen Augen ewig ein Rätsel bleiben" (FA 1.9:927-28; As far as I know these holy men, it seems that their worthy intention is to separate what is connected and connect what is separated. What sort of fabric can emerge from this may forever remain a riddle to our profane eyes).

On the other hand, Wilhelm's recognition that contingent events can display Zusammenhang recalls his own definition of the form of the novel from the seventh chapter of the fifth book. Unlike drama, which is governed by "Schicksal" (fate), the novel permits the play of "Zufall" (contingency) - on the condition that it be "gelenkt und geleitet" (FA 1.9:676; steered and directed) by the attitudes of human agents. As is emphasized by his direct quotation of the stranger's words 'to steer and direct,' Wilhelm's substitution of the Zusammenhang of fate with the Zusammenhang of contingency indicates an implicit awareness that he is not-as he had formerly imagined-the hero of a Shakespearean drama, subject to the slings and arrows of any sort of fortune, but the protagonist of Goethe's novel. As such, the course of his life has developed according to the organizational principle pertaining to the latter. Although it might be objected that this reading introduces a performative contradiction into the novel, insofar as it motivates the contingency of its plot by means of an overarching idea (to account for the emergence of order without teleology), this criticism would only be valid if Goethe had set out-in the 1770's, 
years before the publication of Kant's Kritik der Urteils$k r a f t$, when he penned the first cotyledonesque pages of his novel - with that idea in mind.

\section{Toward a Morphological Aesthetic}

In his well-known fragment titled "Morphologie" (undated), Goethe declares that the principles of his new science should extend "zur geistigen Äußerung des Menschen" (LA 1.10:128; to the intellectual expression of the human being). The potential bearing of morphology on art and aesthetics is again indicated in the general introduction to his morphological notebooks, which proposes that the connection between these disparate practices is self-evident: "Wie nah dieses wissenschaftliche Verlangen mit dem Kunst- und Nachahmungstriebe zusammenhänge, braucht wohl nicht umständlich ausgeführt zu werden" (FA 1.24:391; We need not go into much detail about how closely this scientific desire hangs together with the artistic and mimetic drives). Although Goethe casually dismisses the need to explain the analogy of natural and artistic production, his use of the verb "zusammenhängen"- which he had just used as a noun in the previous sentence to describe the inner connection of "äußern sichtbaren, greiflichen Teile" (FA 1.24:55; outward, visible, tangible parts) in an organic whole-provides a clue, in that it suggests that nature and art hang together (externally) by virtue of the (inner) Zusammenhang involved in both cases.

True to his word, the closest that Goethe comes to articulating a "technische Morphologie" (FA 1.18:483; technical morphology) that would extend his theory from nature to art consists in a brief remark from his introduction to the Propyläen (1798). Here, he describes the inner nexus of literary motives in a work of art as its intellectual (geistige) component:

Die geistige [Behandlung] arbeitet den Gegenstand in seinem innern Zusammenhange aus, sie findet die untergeordneten Motive, und wenn sich bei der Wahl des Gegenstandes überhaupt die Tiefe des künstlerischen Genies beurteilen läßt, so kann man an der Entdeckung der Motive seine Breite, seinen Reichtum, seine Fülle und Liebenswürdigkeit erkennen. (FA 1.18:466)

The intellectual [treatment] works the object out in its inner nexus; it discovers the subordinated motifs. If the depth of artistic genius can be judged by the general choice of object, then its breadth, richness, fullness and affability can be recognized in the discovery of motifs.

If the motifs of a work of art can be compared to the parts of an organism-as is strongly implied by Goethe's references to comparative anatomy from the same essay-then their "inner[er] Zusammenhang" can be compared to the harmony of an organic whole, which consists in the repetition, variation, and combination of relatively simple parts. ${ }^{51}$ This in turn implies that artistic production and reception might be conceived, reciprocally, in terms of natural production and

Karl Philipp Moritz The aesthetic implications of Goethe's morphological project can productively be compared with the aesthetic theory of Karl Philipp Moritz, whose essay "Über die bildende Nachahmung des Schönen" (1788; On the Pictorial Imitation of the Beautiful), which was written in response to his conversations with Goethe in Italy, stakes out a position midway between Rationalism and Transcendental Idealism. Here, Moritz conceives of a work of art's nexus as a compensatory substitution for the nexus of nature, which is beyond the grasp of the human understanding: "je mehrere [Zusammenhang befördernde Beziehungen] eine schöne Sache von ihren einzelnen Theilen zu ihrem Zusammenhange, das ist, zu sich selber hat, um desto schöner ist sie" (the more [nexus-promoting relations] a beautiful thing has from its individual parts to their nexus (i.e., to itself) the more beautiful it is).

i. Karl Philipp Moritz, Schriften zur Ästhetik, ed. Christof Wingertszahn (Stuttgart: Reclam, 2018), 28; see FA 1.15:572-581. For similarities between Goethe's and Moritz's aesthetic, see David E. Wellbery, "Form und Idee: Skizze eines Begriffsfeldes um 1800," in Maatsch (ed.), Morphologie und Moderne 17-42. See also the entry Begriff in this installment of the GLPC, which considers Goethe's collaboration with Moritz on the Nachahmung-essay with reference to their understanding of all philosophical concepts-including Begriff-in terms of graded series of interconnected terms that move together toward greater comprehension or inclusiveness. 
morphology: the poet transforms and arranges motifs into complex organizational structures, which are then mentally rearranged by the reader into series that facilitate their overview. ${ }^{52}$

Although Goethe was attracted to the analogy that Kant had drawn between nature and art, his presentation of their relationship amounts to what orthodox Kantians-as Goethe recalls in his essay on the influence of contemporary philosophy-described as "ein Analogon Kantischer Vorstellungsart, aber ein seltsames" (FA 1.24:445; an analogue to Kantian thought, but a strange one). Indeed, the terms of Goethe's analogy-together with the tertium comparationis connecting them-diverge considerably from those elaborated by his philosophical antecedents, such that the differences introduced in his theory of nature are reflected in the differences introduced in his theory of art. Unlike an absolute system, the parts - as Goethe conceives them - add up to a whole that is no less dynamic than its protean components. Unlike a mere ag- gregate, this whole conditions the transformation of its parts by defining the circumstances to which they must adapt. Hence, while Goethe agrees with Baumgarten that the work of art comprises a nexus of motifs and themes, he rejects the hierarchy that Baumgarten had appropriated from Leibniz's system of pre-established harmony. And while Goethe agrees with Kant that the work of art involves purposiveness without purpose, he seeks to account for this purposiveness without making the transcendental presupposition of a nexus finalis. The complex relation of part to whole that is thematized and performed in Die Wahlverwandtschaften, as well as the nexus of contingent events that is thematized and performed in Wilhelm Meisters Lehrjahre, have been offered as illustrations of these two points. ${ }^{53}$

Ross Shields

Leibniz Center for Literary and Cultural Research, Berlin 


\section{Notes}

${ }^{1}$ For the survival of the nexus concept into the nineteenth century, see Laurence Dickey, "Philosophizing in History in the Nineteenth Century: Zusammenhang and the 'Progressive Method' in German Historical Scholarship," in The Cambridge History of Philosophy in the Nineteenth Century, eds. Allen W. Wood and Songsuk Susan Hahn (Cambridge, UK: Cambridge UP, 2012), 793-816. Hereafter cited as (Dickey, "Philosophizing in History"). See also Frithjof Rodi, Diltheys Philosophie des Lebenszusammenhangs (Freiburg: Verlag Karl Alber, 2018); Walter Gebhard, Der Zusammenhang der Dinge: Weltgleichnis und Naturverklärung im Totatlitätsbewußtsein des 19. Jahrhunderts (Tübingen: Max Niemeyer, 1984).

${ }^{2}$ Dickey, "Philosophizing in History," 796.

${ }^{3}$ Alexander Baumgarten, Metaphysik, trans. Georg Friedrich Meier (Halle: Hemmerde, 1766), §14; Baumgarten, Metaphysics: A Critical Translation with Kant's Elucidations, Selected Notes and Related Materials, trans. and eds. Courtney D. Fugate and John Hymers (London: Bloomsbury, 2014), §14. Hereafter cited as (Baumgarten, Metaphysics). Meier's translation of the Latin nexus as "Der Zusammenhang, die Verbindung und Verknüpfung" follows Baumgarten's annotation to the fourth edition of the Metaphysica (1757), which had glossed the term as "der Zusammenhang, die Verknüpfung." Baumgarten, Metaphysica, 4th ed. (Halle: Hemmerde, 1757). This is consistent with the language employed in Meier's own Auszug aus der Vernunftlehre (1752), which had defined reason as the faculty "den Zusammenhang der Dinge deutlich einzusehen" (to distinctly apprehend the nexus of things). Georg Friedrich Meier, (Auszug aus der Vernunftlehre), in Immanuel Kant, Gesammelte Schriften (AA), ed. Berlin Brandenburg Academy of Sciences (Berlin: de Gruyter, 1900-), 16:301. The academy edition of Kant's writings is hereafter cited as (Kant, AA) in the body of the text. All translations mine unless otherwise indicated. In the margins of his personal copy of Meier's book, Kant dutifully copied out the following definition of reason: "Vernunft ist diejenige Fahigkeit [sic] des Verstandes, wodurch man im Stande ist, den Zusammenhang der Dinge mit ihren Gründen deutlich einzusehen" (Kant, AA 16:94; reason is the capacity of the understanding whereby one is able to distinctly apprehend the nexus of things with their grounds). Erich Adikes dates Kant's study of Meier's Einleitung in die Vernunftlehre to the mid 1750's. See Kant, AA 16: V.

${ }^{4}$ See Norbert Hinske, "Zwischen Aufklärung und Vernunftkritik: Die philosophische Bedeutung des Kantschen Logikcorpus," Aufklärung 7, no. 1 (1993): 57-71. Although there is a wealth of scholarship comparing and contrasting Goethe with Kant, it is only recentlybeginning with Géza von Molnár's study of the marginalia of Goethe's editions of the first and third critique in the 1980's, furthered by Eckart Förster's work on the intuitive understanding, and most recently taken up in a dissertation by Michael Saman - that scholars have begun to exhume what Peter Fenves calls the "real influence" (as opposed to what Ernst Cassirer describes as a " "pre-established harmony" ") of Kant on Goethe. Peter Fenves, "A Critical Relation: On Géza von Molnár's Goethe Scholarship," Goethe Yearbook 11 (2002): 27. The classical comparisons of Goethe and Kant are, of course, those by Ernst Cassirer and Georg Simmel. See Géza von Molnár, Goethes Kantstudien: Eine Zusammenstellung nach Eintragungen in seinen Handexemplaren der "Kritik der reinen Vernunft" und der "Kritik der Urteilskraft" (Weimar:
Verlag Hermann Böhlaus, 1994); Georg Simmel, Kant und Goethe, ed. Cornelius Curlitt (Berlin: Bard Marquarde \& Co, 1906), 5; Ernst Cassirer, Gesammelte Werke, ed. Birgit Recki (Hamburg: Felix Meiner Verlag, 2007), 16:473-74; Eckart Förster, Die 25 Jahre der Philosophie: Eine systematische Rekonstruktion (Frankfurt a.M.: Vittorio Klostermann, 2011). Hereafter cited as (Förster, 25 Jahre). See also Clark Muenzer, "Goethe's Metaphysics of Immanence," Colloquia Germanica 39, no. 1 (2006): 1-19; Michael Saman, "Goethe as a Reader of Kant, 1788-1832: Judgment, Grace, and the Most Desirable Calling" (PhD diss., Harvard U, 2010); Oliver Simons, "Simmel's Poetics of Forms," Germanic Review 94, no. 2 (2019): 101-13.

${ }^{5}$ See Kant, AA 25:9. See also Ross Shields, "Aggregat," in Formen des Ganzen, eds. Eva Geulen and Claude Haas, (Göttingen: Wallstein, forthcoming). For the relation between the early-romantic and Kantian concept of a system, see Christian Strub, "System," in Historisches Wörterbuch der Philosophie (Basel: Schwabe, 1998), 10:824-55; Andreas Arndt, "Friedrich Schlegels dialektischer Systembegriff," in System und Systemkritik um 1800, eds. Christian Danz and Jürgen Stolzenberg (Hamburg: Felix Meiner, 2011), 287-300; Sarah Schmidt, Die Konstruktion des Endlichen: Schleiermachers Philosophie der Wechselwirkung (Berlin: de Gruyter, 2012), 48. See also the entry Begriffin this installment of the GLPC for Goethe's understanding of "Summe" and "Resultat."

${ }^{6}$ For Goethe's critique of Blumenbach, see "Bildungstrieb," in FA 1.24:451-452. For Goethe's relation to Linnaeus, see Robert Stockhammer, "Darstellung der Metamorphose, wissenschaftlich und poetisch: Ansätze zu einer anderen Theorie des Symbols bei Goethe," in Aktualität des Symbols, eds. Frauke Berndt and Christoph Brecht (Freiburg: Rombach Verlag, 2005), 58-60. See Jocelyn Holland, “'Eine Art Wahnsinn': Intellektuelle Anschauung und Goethes Schriften zur Metamorphose," in Intellektuelle Anschauung: Figurationen von Evidenz zwischen Kunst und Wissen, eds. Sibylle Peters and Martin Jörg Schäfer (Bielefeld: transcript Verlag, 2006), 83-84.

${ }^{7}$ For more on the "mereologischen Präzedenz" of the whole over its part, see Carlos Spoerhase, Das Format der Literatur: Praktiken materieller Textualität zwischen 1740 und 1830 (Göttingen: Wallstein, 2018), 459ff. Hereafter cited as (Spoerhase, Das Format der Literatur).

${ }^{8}$ For the relation of Goethe's morphology to Spinoza and Kant, see Eckart Förster, "Die Bedeutung von $§ \S 76,77$ der Kritik der Urteilskraft für die Entwicklung der nachkantischen Philosophie. Teil I," in Kant und der Frühidealismus, ed. Jürgen Stolzenberg (Hamburg: Felix Meiner Verlag, 2007), 59-80; Förster, 25 Jahre. For an influential reading of Goethe's relation to Plato and Kant, see Elizabeth Rotten, Goethes Urphänomen und die platonische Idee (Gießen: Verlag von Alfred Töpelmann, 1913). For Goethe and German Idealism, see Förster, "Die Bedeutung von $§ \S 76,77$ der Kritik der Urteilskraft für die Entwicklung der nachkantischen Philosophie. Teil II," Zeitschrift für philosophische Forschung, 56, no. 3 (2002): 169-90. Hereafter cited as (Förster, "Bedeutung II"). See also Elizabeth Millán-Zaibert and John H. Smith (eds.), Goethe and Idealism: Art, Science, Religion, and Philosophy-1790 to 1817, Special Issue of Goethe Yearbook, 18 (2011). For a mystical interpretation, see Rudolf Steiner, Grundlinien einer Erkenntnistheorie der Goetheschen Weltanschauung mit besonderer Rücksicht auf Schiller (Basel: Rudolf Steiner Verlag, 2011). I develop a more detailed interpretation of Goethe's reading of Kant in my dissertation and forthcoming monograph. See Ross Shields, "Hanging-Together: 
Kant, Goethe, and the Theory of Aesthetic Modernism" (PhD diss., Columbia U, 2019), 75-122; Ross Shields, The Critique of Pure Feeling: Goethe Reading Kant (forthcoming).

${ }^{9}$ Unless otherwise noted, works by Goethe are cited by section, volume, and page numbers according to the Frankfurt edition (FA): Johann Wolfgang Goethe, Sämtliche Werke, Briefe, Tagebücher und Gespräche, eds. Hendrik Birus, Dieter Borchmeyer, Karl Eibl, et. al., 40 vols. (Frankfurt a.M.: Deutscher Klassiker Verlag, 1987-2013), 1.7:34.382-83. Hereafter cited as FA in the body of the text.

${ }^{10}$ See Gottfried Wilhelm Leibniz, Monadology, in Discourse on Metaphysics, trans. Georg Montgomery (La Salle: Open Court Classics, 1993), §51. Hereafter cited as (Leibniz, Monadology). See also Christian Wolff, Vernünftige Gedanken von Gott, der Welt und der Seele des Menschen, auch allen Dingen überhaupt (Hildesheim: Georg Olms Verlag, 1983), §605; Baumgarten, Metaphysics §461; Georg Friedrich Meier, Beweis der vorherbestimmten Uebereinstimmung (Halle: Carl Hermann Hemmerde, 1743). Leibniz invokes the choir metaphor in his letter to Arnauld from April 30th, 1687. See Leibniz, Correspondence with Arnauld, in Discourse on Metaphysics, trans. Georg Montgomery (La Salle: Open Court Classics, 1993), 188.

${ }^{11}$ As Leibniz writes, they "have no windows." Leibniz, Monadology §7. See Leibniz, New Essays on Human Understanding, trans. and eds. Peter Remnant and Jonathan Bennett (Cambridge, UK: Cambridge UP, 1997), 254-59; Baumgarten, Metaphysics, §640.

${ }^{12}$ Baumgarten, Reflections on Poetry, trans. and eds. Karl Aschenbrenner and William B. Holther (Berkeley: U of California P: 1954), §68. Herafter Cited as (Baumgarten, Poetry).

${ }^{13}$ Baumgarten, Poetry $§ 65$; translation revised by RS.

${ }^{14}$ See Baumgarten, Metaphysics $\$ 520$.

${ }^{15}$ For the relation between rationalist metaphysics and aesthetics, see Rüdiger Campe, "Effekt der Form: Baumgartens Ästhetik am Rande der Metaphysik," in Baumgarten-Studien: Zur Genealogie der Ästhetik, eds. Rüdiger Campe, Anselm Haverkamp, and Christoph Menke (Berlin: August Verlag, 2014), 117-144. For Johann Bodmer's and Johann Breitinger's related attempts to extend Leibniz's cosmology to the work of art, see M. H. Abrams, Doing Things with Texts: Essays in Criticism and Critical Theory, ed. Michael Fischer (New York: Norton, 1991), 169ff.

${ }^{16}$ Johann Heinrich Zedler, Grosses vollständiges Universal-Lexicon, (Halle: Zedler, 1750), 64:567-585.

${ }^{17}$ Kant's words were recorded by Mrongovius in 1782 .

${ }^{18}$ See Kant, AA 29: 867.

${ }^{19}$ See Kant, AA 29: 880.

${ }^{20}$ Note that Kant uses the terms nexus realis and nexus idealis in the Kritik der Urteilskraft in a different sense, as synonyms of the nexus effectivus and nexus finalis, respectively. Kant, Kritik der Urteilskraft, ed. Wilhelm Weischedel (Frankfurt a.M.: Suhrkamp, 1974), B290, A286. Hereafter cited as (Kant, KU). This is confusing, because the nexus finalis is a transcendent concept that would seem to correspond to the nexus realis from the lectures on metaphysics, whereas the nexus effectivus takes place among appearances, which the lectures on metaphysics describe as a nexus idealis. As far as I can tell, this is no more than a terminological confusion, albeit one that indicates the ambiguity of the real in reference to Kant's concept of appearances.

${ }^{21}$ See Immanuel Kant, Kritik der reinen Vernunft, ed. Wilhelm Weischedel (Frankfurt a.M.: Suhrkamp, 1974), A389; A583, B661; A619, B647. Hereafter cited as (Kant, KrV).

${ }^{22}$ Kant, Critique of Pure Reason, trans. and ed. Paul Guyer and Allen W. Wood (New York: Cambridge UP, 1998), B673, A645. Hereafter cited as (Guyer and Wood).

${ }^{23}$ See Peter McLaughlin, "Transcendental Presuppositions and Ideas of Reason," Kant-Studien 105, no. 4 (2014): 554-72.

${ }^{24}$ See Kant, KU B32-34, A33-34; B267-70, A263-66.

${ }^{25}$ See Walter Benjamin, Der Begriff der Kunstkritik in der deutschen Romantik, in Gesammelte Schriften, vol. 1.1, eds. Rolf Tiedemann and Hermann Schweppenhäuser (Frankfurt a.M.: Suhrkamp Verlag, 1990), 19; Förster, "Bedeutung II."

${ }^{26}$ For the loose coherence of Goethe's late literary production, including reflections on its non-systematic form in terms of aggregation, see Volker Neuhaus, "Die Archivfiktion in Wilhelm Meisters Wanderjahren," Euphorion 62 (1968): 13-27; Martin Bez, "Wilhelm Meisters Wanderjahren": Aggregat, Archiv, Archivroman (Berlin: De Gruyter, 2013), 57-65; Geulen, Aus dem Leben der Form: Goethes Morphologie und die Nager (Berlin: August Verlag, 2016), 136. Hereafter cited as (Geulen, Aus dem Leben). See also Bryan Klausmeyer, "Signs of Life: Form, Life, and the Materiality of Writing around 1800 (Georg Christoph Lichtenberg - Jean Paul - Goethe)" (PhD diss., John Hopkins U, 2016), 266-76; Spoerhase, Das Format der Literatur, 511-28.

${ }^{27}$ See Alfred North Whitehead, Process and Philosophy: An Essay in Cosmology, eds. David Ray Griffin and Donald W. Sherburne (New York: The Free P, 1978); Gilles Deleuze and Félix Guattari, $A$ Thousand Plateaus: Capitalism and Schizophrenia, trans. Brian Massumi (London: Continuum, 2003); Jane Bennett, Vibrant Matter: A Political Ecology of Things (Durham: Duke UP, 2010). See also the entry Begriff in this installment of the $G L P C$, where Whitehead, along with Deleuze and Guattari, are briefly discussed.

${ }^{28}$ The readings of Goethe's late novels presented here are elaborated in my forthcoming monograph. See Ross Shields, The Critique of Pure Feeling: Goethe Reading Kant (forthcoming).

${ }^{29}$ See Kant, KrV B671, A643.

${ }^{30}$ See Kant, KU B295-96, A292.

${ }^{31}$ For an interpretation of the poetological structure of Goethe's Farbenlehre, see Joel B. Lande, "Form as Bond: Learning to see with Goethe's Zur Farbenlehre," Zeitschrift für deutsche Philologie 138 (2019): 157-77. For Goethe's most elaborate presentation of his method, see "Der Versuch als Vermittler von Objekt und Subjekt," in FA 1.25:26-36.

${ }^{32}$ Goethe, Goethes Gespräche: Eine Sammlung zeitgenössischer Berichte aus seinem Umgang, vol. 5, ed. Wolfgang Herwig (München: dtv Verlagsgesellschaft 1998), 84. Eckart Förster provides the following interpretation of this last sentence: "Der Zusammenhang des Ganzen muss erst hergestellt werden, und das gelingt nur, indem die Übergänge zwischen den (sukzessiven) Teilen gedanklich nachvollzogen und dann alle Übergänge zusammen (simultan) vergegenwärtigt werden. In die- 
sem letzten Schritt wird das Denken intuitiv; es erfasst das Ganze als Ganzes" (The coherence of the whole must first be produced, and that is only possible by mentally reconstructing the transitions between the (successive) parts and then (simultaneously) envisioning all of the transitions together). Förster, "Goethe und die Idee einer Naturphilosophie," in Morphologie und Moderne: Goethes 'anschauliches Denken' in den Geistes- und Kulturwissenschaften seit 1800, ed. Jonas Maatsch (Berlin: De Gruyter, 2014), 54. Hereafter cited as (Maatsch [ed.], Morphologie und Moderne). For Goethe's emphasis on seeing, see Dorothea von Mücke and David Wellbery, eds., Augenmensch: Zur Bedeutung des Sehens im Werk Goethes, Special Issue of Deutsche Vierteljahrschrift für Literaturwissenschaft und Geistesgeschichte 75, no. 1 (January 2001).

${ }^{33}$ For Kant's well-known distinction between empty concepts and blind intuitions, see Kant, KrV B75, A51. See also the entry Begriff in this installment of the GLPC, which discusses the reciprocal relation of Begriff (concept) and Anschauung (intuition) in Goethe's reconstruction.

${ }^{34}$ See FA 1.9:301: "Stelle dir nur das Wasser, das Öl, das Quecksilber vor, so wirst du eine Einigkeit, einen Zusammenhang ihrer Teile finden" (Just imagine water, oil, or mercury and you will discern a unity, a coherence, of their parts). Goethe's use of Zusammenhang to describe the coherence of a chemical substance recalls Kant's definition from the Metaphysische Anfangsgründe der Naturwissenschaft (Metaphysical Foundations of Natural Science): “Anziehung, so fern sie bloß als in der Berührung wirksam gedacht wird, heißt Zusammenhang" (Kant, AA 4:526; Attraction, insofar as it is conceived as effective merely through contact, is called cohesion [Zusammenhang]). For more on Goethe's use of the chemical metaphor, see Eva Horn, "Chemie der Leidenschaft: Johann Wolfgang von Goethes Roman Die Wahlverwandtschaften," in Leidenschaften literarisch, ed. Reingard M. Nischik (Konstanz: Universitätsverlag Konstanz, 1998), 163-82.

${ }^{35}$ In the sixth chapter of the first part, he goes so far as to argue that "[a]lles eigentlich gemeinsame Gute muß durch das unumschränkte Majestätsrecht gefördert werden" (FA 1.8:317; Everything that is truly for the common good must be facilitated by an unrestricted sovereign power). For an interpretation of the Captain's systematic character in terms of administrative cameralism, see Joseph Vogl, "Nomos der Ökonomie: Steurungen in Goethes 'Wahlverwandtschaften,' " in $M L N$ 114, no. 3 (April 1999): 503-27.

${ }^{36}$ See FA 1.8:312, 320.

${ }^{37}$ This difference between Goethe's account and standard theories of part to whole is captured in Amanda Jo Goldstein's description of morphology as a logic of "disorganizing Form." Amanda Jo Goldstein, Sweet Science: Romantic Materialism and the New Logics of Life (Chicago: U of Chicago P, 2017), 89.

${ }^{38} \mathrm{I}$ have chosen to translate Similarteile as 'atomic parts' in order to reserve the word 'similar' as a translation of ähnlich.

${ }^{39}$ Goethe, Scientific Studies, ed. and trans. Douglas Miller (New York: Suhrkamp Publishers New York, 1988), 63; revised by RS. Hereafter ited as Miller in the text.

${ }^{40}$ See FA 1.24:365f.

${ }^{41}$ Translation revised by RS.
${ }^{42}$ For the reception of Goethe's morphology by nineteenth and twentieth century music theorists, see Ross Shields, "Morphology and Music Theory: Variations on a Theme by Goethe," in Eva Axer, Eva Geulen, and Alexandra Heimes, Aus dem Leben der Form: Studien zum Nachleben von Goethes Morphologie in der Theoriebildung des 20. Jahrhundert (Göttingen: Wallstein, forthcoming).

${ }^{43}$ See FA 1.24:582f.

${ }^{44}$ See FA 1.24:109-151.

${ }^{45}$ Also see Günther Müller, Gestaltung-Umgestaltung in Wilhelm Meisters Lehrjahren (Halle: Niemeyer 1948).

${ }^{46}$ Italics removed from the second quotation. Schiller's reading is more subtle (and more Kantian), in that he rejects both sides of the antinomy: "Auf diese Art erhält das Ganze eine schöne Zweckmäßigkeit, ohne daß der Held einen Zweck hätte" (FA 1.9:1264; In this way the whole receives a beautiful purposiveness, without the hero having a purpose).

${ }^{47}$ Johann Wolfgang von Goethe, Gespräche mit Goethe in den letzten Jahren seines Lebens, 3rd ed., ed. Johann Peter Eckermann (Leipzig: F. A. Brockhaus, 1868), 1:135.

${ }^{48}$ See Helmut Müller-Sievers, "Going On: Philosophy of Continuity and the Writing of Coherence in Goethe's Wilhelm Meister's Apprenticeship," in Goethe's Wilhelm Meister's Apprenticeship and Philos$o p h y$, eds. Sarah V. Eldridge and Allen Speight (Oxford: Oxford UP, 2020), 237-68.

${ }^{49}$ For an interpretation of the "Figuraler und Symbolischer Nexus" (figural and symbolic nexus) by means of which the episodes of the Lehrjahre hang together, see Manfred Engel, Der Roman der Goethezeit (Stuttgart: J. B. Metzler, 1993), 1:275-99. For a reflection on the relation of morphology and Goethe's concept of authorship, see Dorothea von Mücke, "Goethe's Metamorphosis: Changing Forms in Nature, the Life Sciences, and Authorship," Representations 95, no. 1 (Summer 2006): 27-53.

${ }^{50}$ The pedagogical dimension of this philosophy is elaborated in the fifth chapter of the eighth book. See FA 1.9: 931.

${ }^{51}$ See FA 1.18:463.

${ }^{52}$ For an interpretation of Goethe's morphology in terms of "poetic procreation," see Jocelyn Holland, German Romanticism and Science: The Procreative Poetics of Goethe, Novalis, and Ritter (New York: Routledge, 2009), 19-55. Eva Geulen concludes her monograph on Goethe's morphology by suggesting (with reference to Walter Benjamin's dissertation on romantic criticism) the possibility of identifying "Goethes Naturforschung in toto als eine Kunsttheorie" (Goethe's study of nature in toto as a theory of art). Geulen, Aus dem Leben, 151. For more on the Zusammenhang of Goethe's Werke as such, see Steffen Martus, Werkpolitik: Zur Literaturgeschichte kritischer Kommunikation vom 17. bis ins 20. Jahrhundert (Berlin: de Gruyter, 2007), 444-513.

${ }^{53}$ For Goethe's reception in the nineteenth century, see note 1 , above. For Goethe's reception in the twentieth century, see Maatsch (ed.), Morphologie und Moderne; Eva Axer, Eva Geulen, and Alexandra Heimes, Aus dem Leben der Form: Studien zum Nachleben von Goethes Morphologie in der Theoriebildung des 20. Jahrhundert (Göttingen: Wallstein, forthcoming). 


\section{Related Entries in the GLPC}

Ästhetisch/Aesthesis (Aesthetic/Aesthetics) Analogie (Analogy) Aperçu (Aperçu) Bildung (Formation) Dynamik/dynamisch (Dynamic/dynamic) Form (Form) Ganzes (Whole) Harmonie (Harmony) Kant Kritik (Critique) Kunst (Art) Leibniz Makro-/Mikrokosmos (Macro-/Microcosm) Metamorphose (Metamorphosis) Morphologie (Morphology) Organismus (Organism) Präformation (Preformation) Reihe (Series) Sammlung (Collection) Schicksal (Fate) Sinnlichkeit (Sensibility) Verstand (Understanding) Verknüpfung (Connection) Wechselwirkung (Interaction) Werden (Becoming) Wissen/Wissenschaft (Knowledge/Science) Zufall (Contingency) Zweckmäßigkeit (Purposiveness)

\section{Works Cited and Further Reading}

Abrams, M. H. Doing Things with Texts: Essays in Criticism and Critical Theory. Edited by Michael Fischer. New York: Norton, 1991.

Arndt, Andreas. "Friedrich Schlegels dialektischer Systembegriff." In System und Systemkritik um 1800, edited by Christian Danz and Jürgen Stolzenberg, 287-300. Hamburg: Felix Meiner, 2011.

Axer, Eva, Eva Geulen, and Alexandra Heimes. Aus dem Leben der Form: Studien zum Nachleben von Goethes Morphologie in der Theoriebildung des 20. Jahrhunderts. Göttingen: Wallstein, forthcoming.

Baumgarten, Alexander. Metaphysica, 4th edition. Halle: Hemmerde, 1757.

-. Metaphysics: A Critical Translation with Kant's Elucidations, Selected Notes and Related Materials. Translated and edited by Courtney D. Fugate and John Hymers. London: Bloomsbury, 2014.

-. Metaphysik. Translated by Georg Friedrich Meier. Halle: Hemmerde, 1766.

-. Reflections on Poetry. Translated and edited by Karl Aschenbrenner and William B. Holther. Berkeley: U of California P: 1954.

Benjamin, Walter. Gesammelte Schriften. Edited by Rolf Tiedemann and Hermann Schweppenhäuser. 16 vols. Frankfurt a.M.: Suhrkamp, 1990.

Bennett, Jane. Vibrant Matter: A Political Ecology of Things. Durham: Duke UP, 2010.
Bez, Martin. "Wilhelm Meisters Lehrjahre": Agregat, Archiv, Archivroman. Berlin: De Gruyter, 2013.

Campe, Rüdiger. "Effekt der Form: Baumgartens Ästhetik am Rande der Metaphysik." In Baumgarten-Studien: Zur Genealogie der Ästhetik, edited by Rüdiger Campe, Anselm Haverkamp, and Christoph Menke, 117-144. Berlin: August Verlag, 2014.

Cassirer, Ernst. Gesammelte Werke. Edited by Birgit Recki. 26 vols. Hamburg: Felix Meiner Verlag, 2009.

Deleuze, Gilles and Félix Guattari. A Thousand Plateaus: Capitalism and Schizophrenia. Translated by Brian Massumi. London: Continuum, 2003.

Dickey, Laurence. "Philosophizing about History in the Nineteenth Century: Zusammenhang and the 'Progressive Method' in German Historical Scholarship." In The Cambridge History of Philosophy in the Nineteenth Century, edited by Allen W. Wood and Songsuk Susan Hahn, 793-816. Cambridge, UK: Cambridge UP, 2012.

Engel, Manfred. Der Roman der Goethezeit, volume 1. Stuttgart: J. B. Metzler, 1993.

Fenves, Peter. "A Critical Relation: On Géza von Molnár's Goethe Scholarship." Goethe Yearbook 11 (2002): 27-31.

Förster, Eckart. Die 25 Jahre der Philosophie: Eine systematische Rekonstruktion. Frankfurt a.M.: Vittorio Klostermann, 2011.

—. "Die Bedeutung von $§ \S 76,77$ der Kritik der Urteilskraft für die Entwicklung der nachkantischen Philosophie. Teil I." In Kant und der Frühidealismus, edited by Jürgen Stolzenberg, 59-80. Hamburg: Felix Meiner Verlag, 2007.

—. "Die Bedeutung von $§ \S 76,77$ der Kritik der Urteilskraft für die Entwicklung der nachkantischen Philosophie. Teil II." Zeitschrift für philosophische Forschung 56, no. 3 (2002): 169-90.

-. "Goethe und die Idee einer Naturphilosophie." In Maatsch (editor) Morphologie und Moderne, 43-56.

Gebhard, Walter. Der Zusammenhang der Dinge: Weltgleichnis und Naturverklärung im Totalitätsbewußtsein des 19. Jahrhunderts. Tübingen: Max Niemeyer, 1984.

Geulen, Eva. Aus dem Leben der Form: Goethes Morphologie und die Nager. Berlin: August Verlag, 2016.

Goethe, Johann Wolfgang von. Die Schriften zur Naturwissenschaft (LA). Edited by Dorothea Kuhn. Weimar: Hermann Böhlaus Nachfolger, 1986. 
-. Gespräche mit Goethe in den letzten Jahren seines Lebens, volume 1. 3rd edition. Edited by Johann Peter Eckermann. Leipzig: F. A. Brockhaus, 1868.

-. Goethes Gespräche 1819-1823. Edited by Woldemar von Biedermann. Leibzig: Biedermann, 1889.

-. Sämtliche Werke (FA). Edited by Hendrick Birus, Dieter Borchmeyer, Karl Eibl, et al. 40 volumes. Frankfurt a.M.: Deutscher Klassiker Verlag, 1987-2013.

-. Scientific Studies. Edited and translated by Douglas Miller. New York: Suhrkamp Publishers New York, 1988.

Goldstein, Amanda Jo. Sweet Science: Romantic Materialism and the New Logics of Life. Chicago: U of Chicago P, 2017.

Hoffmann, E. T. A. Die Serapions-Brüder. Frankfurt a.M.: Insel, 1983.

Holland, Jocelyn. “'Eine Art Wahnsinn': Intellektuelle Anschauung und Goethes Schriften zur Metamorphose." In Intellektuelle Anschauung: Figurationen von Evidenz zwischen Kunst und Wissen, edited by Sibylle Peters and Martin Jörg Schäfer, 79-92. Bielefeld: transcript Verlag, 2006.

-. German Romanticism and Science: The Procreative Poetics of Goethe, Novalis, and Ritter. New York: Routledge, 2009.

Hinske, Norbert. "Zwischen Aufklärung und Vernunftkritik: Die philosophische Bedeutung des Kantschen Logikcorpus." Aufklärung 7, no. 1 (1993): 57-71.

Horn, Eva. "Chemie der Leidenschaft: Johann Wolfgang von Goethes Roman Die Wahlverwandtschaften." In Leidenschaften literarisch, edited by Reingard M. Nischik, 16382. Konstanz: Universitätsverlag Konstanz, 1998.

Kant, Immanuel. Critique of Pure Reason. Translated and edited by Paul Guyer and Allen W. Wood. New York: Cambridge UP, 1998.

-. Gesammelte Schriften (AA). Edited by the Berlin Brandenburg Academy of Sciences. 29 volumes. Berlin: de Gruyter, 1900-.

-. Kritik der reinen Vernunft (KrV). Edited by Wilhelm Weischedel. Frankfurt a.M.: Suhrkamp, 1974.

-. Kritik der Urteilskraft (KU). Edited by Wilhelm Weischedel. Frankfurt a.M.: Suhrkamp, 1974.

Klausmeyer, Bryan. "Signs of Life: Form, Life, and the Materiality of Writing around 1800 (Georg Chris- toph Lichtenberg - Jean Paul - Goethe)" (PhD diss., John Hopkins U, 2016).

Lande, Joel B. "Form as Bond: Learning to see with Goethe's Zur Farbenlehre." Zeitschrift für deutsche Philologie 138 (2019): 157-177.

Leibniz, Gottfried Wilhelm. Correspondence with Arnauld. In Discourse on Metaphysics, translated by Georg Montgomery, 66-248. La Salle: Open Court Classics, 1993.

-. Monadology. In Discourse on Metaphysics, translated by Georg Montgomery, 249-72. La Salle: Open Court Classics, 1993.

-. New Essays on Human Understanding. Translated and edited by Peter Remnant and Jonathan Bennett. Cambridge, UK: Cambridge UP, 1997.

-. Theodicy: Essays on the Goodness of God the Freedom of Man and the Origin of Evil. Edited by Austin Farrer. Translated by E. M. Huggard. Chicago: Open Court, 1990.

Lewis, C. T. and Charles Short. A Latin Dictionary. Oxford: Clarendon P, 1879.

Maatsch, Jonas (editor), Morphologie und Moderne: Goethes 'anschauliches Denken' in den Geistes- und Kulturwissenschaften seit 1800. Berlin: De Gruyter, 2014.

Martus, Steffen. Werkpolitik: Zur Literaturgeschichte kritischer Kommunikation vom 17. bis ins 20. Jahrhundert. Berlin: de Gruyter, 2007.

McLaughlin, Peter. "Transcendental Presuppositions and Ideas of Reason." Kant-Studien 105, no. 4 (2014): 554-72.

Meier, Georg Friedrich. Beweis der vorherbestimmten Uebereinstimmung. Halle: Carl Hermann Hemmerde, 1743.

Millán-Zaibert, Elizabeth and John H. Smith, eds. Goethe and Idealism: Art, Science, Religion, and Philosophy-1790 to 1817. Special Issue of Goethe Yearbook 18 (2011).

Molnár, Géza von. Goethes Kantstudien: Eine Zusammenstellung nach Eintragungen in seinen Handexemplaren der "Kritik der reinen Vernunft" und der "Kritik der Urteilskraft.” Weimar: Verlag Hermann Böhlaus, 1994.

Moritz, Karl Philipp. Schriften zur Ästhetik. Edited by Christof Wingertszahn. Stuttgart: Reclam, 2018.

Mücke, Dorothea von. "Goethe's Metamorphosis: Changing Forms in Nature, the Life Sciences, and 
Authorship." Representations 95, no. 1 (Summer 2006): 27-53.

Mücke, Dorothea von. and David Wellbery, eds. Augenmensch: Zur Bedeutung des Sehens im Werk Goethes. Special Issue of Deutsche Vierteljahrschrift für Literaturwissenschaft und Geistesgeschichte 75, no. 1 (January 2001).

Müller, Günther. Gestaltung-Umgestaltung in Wilhelm Meisters Lehrjahren. Halle: Niemeyer, 1948.

Müller-Sievers, Helmut. "Going On: Philosophy of Continuity and the Writing of Coherence in Goethe's Wilhelm Meister's Apprenticeship." In Goethe's Wilhelm Meister's Apprenticeship and Philosophy, edited by Sarah V. Eldridge and Allen Speight, 237-68. Oxford: Oxford UP, 2020.

Muenzer, Clark. "Goethe's Metaphysics of Immanence." Colloquia Germanica 39, no. 1 (2006): 1-19.

Neuhaus, Volker. "Die Archivfiktion in Wilhelm Meisters Wanderjahren." Euphorion 62 (1968): 13-27.

Rodi, Frithjof. Diltheys Philosophie des Lebenszusammenhangs: Strukturtheorie - Hermeneutik - Anthropologie. Freiburg: Verlag Karl Alber, 2018.

Rotten, Elizabeth. Goethes Urphänomen und die platonische Idee. Gießen: Verlag von Alfred Töpelmann, 1913.

Rowe, M. W., "Goethe and Wittgenstein.” Philosophy 66 (Jul 1991): 283-303.

Saman, Michael. "Goethe as a Reader of Kant, 1788-1832: Judgment, Grace, and the Most Desirable Calling" (PhD diss., Harvard U, 2010).

Schulte, Joachim. "Ideen mit den Augen sehen: Goethe und Wittgenstein über Morphologie." In Maatsch (editor), Morphologie und Moderne, 141-156.

Schmidt, Sarah. Die Konstruktion des Endlichen: Schleiermachers Philosophie der Wechselwirkung. Berlin: de Gruyter, 2012.

Schütz, Wilhelm von. Zur intellectuellen und substantiellen Morphologie, volume 1. Leipzig, 1821.

Sebdner, Helmut. Schütz-Lacrimas: Das Leben des Romantikerfreundes, Poeten, und Literaturkritikers Wilhelm von Schütz. Berlin: Erich Schmidt Verlag, 1974.

Shields, Ross. "Aggregat." In Formen des Ganzen, edited by Eva Geulen and Claude Haas (Göttingen: Wallstein, forthcoming).
-. "Hanging-Together: Kant, Goethe, and the Theory of Aesthetic Modernism" (PhD diss., Columbia U, 2019).

-. "Morphology and Music Theory: Variations on a Theme by Goethe." In Eva Axer, Eva Geulen, and Alexandra Heimes, Aus dem Leben der Form: Studien zum Nachleben von Goethes Morphologie in der Theoriebildung des 20. Jahrhundert (Göttingen: Wallstein, forthcoming).

-. The Critique of Pure Feeling: Goethe Reading Kant (forthcoming).

Simmel, Georg. Kant und Goethe. Edited by Cornelius Curlitt. Berlin: Bard Marquarde \& Co, 1906.

Simons, Oliver. "Simmel's Poetics of Forms." Germanic Review 94, no. 2 (2019): 101-13.

Spoerhase, Carlos. Das Format der Literatur: Praktiken materieller Textualität zwischen 1740 und 1830. Göttingen: Wallstein, 2018.

Steiner, Rudolf. Grundlinien einer Erkenntnistheorie der Goetheschen Weltanschauung mit besonderer Rücksicht auf Schiller. Basel: Rudolf Steiner Verlag, 2011.

Stockhammer, Robert. "Darstellung der Metamorphose, wissenschaftlich und poetisch: Ansätze zu einer anderen Theorie des Symbols bei Goethe." In Aktualität des Symbols, edited by Frauke Berndt and Christoph Brecht, 53-76. Freiburg: Rombach Verlag, 2005.

Strub, Christian. "System." In Historisches Wörterbuch der Philosophie, 10:824-55. Basel: Schwabe, 1998.

Vogl, Joseph. "Nomos der Ökonomie: Steurungen in Goethes 'Wahlverwandtschaften.'" $M L N 114$, no. 3 (April 1999): 503-27.

Wellbery, David E. "Form und Idee: Skizze eines Begriffsfeldes um 1800." In Maatsch (editor) Morphologie und Moderne, 7-42.

Whitehead, Alfred North. Process and Philosophy: An Essay in Cosmology. Edited by David Ray Griffin and Donald W. Sherburne. New York: The Free P, 1978.

Wittgenstein, Ludwig. Wiener Ausgabe. Edited by Michael Nedo. 5 vols. Vienna: Springer, 1995.

Wolff, Christian. Vernünftige Gedanken von Gott, der Welt und der Seele des Menschen, auch allen Dingen überhaupt. Hildesheim: Georg Olms Verlag, 1983.

Zedler, Johann Heinrich. Grosses vollständiges Universal-Lexicon, 64 vols. Halle: Zedler, 1750. https://www. zedler-lexikon.de/index.html?c=blaettern\&bandnummer $=01 \&$ seitenzahl $=40 \& \mathrm{l}=\mathrm{de}$ 